\title{
The Psychological Imperative in Political Processes in Nigeria
}

\author{
Godwyns Ade' Agbude1, Ayotunde Elegbeleye ${ }^{2}$, Joy Godwyns-Agbude, \\ Excellence-Oluye Nchekwube ${ }^{1}$ \\ ${ }^{1}$ Department of Political Science and International Relations, School of Human Resource Development, \\ College of Leadership Development Studies, Covenant University, Ota, Nigeria \\ ${ }^{2}$ Department of Psychology, School of Human Resource Development, College of Leadership Development \\ Studies, Covenant University, Ota, Nigeria \\ ${ }^{3}$ Charis Center of Leadership Development, Ado-Ekiti, Nigeria \\ Email: godwyns.agbude@covenantuniversity.edu.ng, agodwins1@yahoo.com, \\ ayo.elegbeleye@covenantuniversity.edu.ng, joygodwyns@yahoo.com, chekwubeugbede@gmail.com
}

Received 22 October 2014; revised 23 November 2014; accepted 2 December 2014

Copyright (C) 2014 by authors and Scientific Research Publishing Inc.

This work is licensed under the Creative Commons Attribution International License (CC BY).

http://creativecommons.org/licenses/by/4.0/

(c) (i) Open Access

\section{Abstract}

The nature of politics involves the coordination of peaceful human co-existence. Given its central place in human existence, politics has a great importance in fostering a better living condition of people. But when wrongly pursued and exercised, political power becomes a destructive tool in the hands of political leaders. In view of this importance, it becomes an imperative to subject those vying for political positions to psychological (personality) test in order to validate their fitness and usefulness in ensuring the purpose of politics which among others includes the coordination of human society. This paper employs observatory, dialogical and discursive methods in examining the interlock between politics and psychology. It highlights some abnormal behaviours displayed by our political leaders and argues that the withdrawer of psychology and psychologists to the background in political matters in Nigeria spells doom for the country at large. Thus, it recommends that there must be a deliberate fusion of politics (political science) and psychology, beyond mere referencing them as belonging to the social sciences. In other words, there must be a deliberate intellectual merger of politics and psychology within the university system and the public sphere. It also recommends that psychologists should get involved in national discourse not just as citizens but also as professionals who can provide answers to national issues especially in regards to analyzing the behaviours of political leaders and determining whom are fit to lead. Finally, it holds that the civil society and psychologists have a viable role to play in redressing the socio-political "madness" in the corridor of power in Nigeria. Importantly, this paper does not discuss the wide variety of personality tests and does not pretend to have conducted any personality test on any public office holder, but suggests that personality tests are necessary in order to ensure sanity in our polity by recruiting the "right people"-people without personality disorder 
and leaders that will not jeopardize the well-being of the people.

Keywords

Politics, Psychology, Behaviours, Leadership and Personality

\section{Introduction}

Man is a complex being. He is not only a physical being, but also an ethical, spiritual, psychological, metaphysical, social and political being among others. Thus, all academic disciplines exist to demystify the being of man, empowering him to dominate his environment and assisting him to live a life of happiness. It is therefore important to state that no discipline can be subsumed under any other since all have their relevance in demystifying the being of man in one area or the other. And none should be given a magisterial position over the other. However, in this paper, we focus on the political and the psychological dimensions of man.

The life of man is intertwined within the concept of politics. This is because man exists to satisfy some basic and fundamental needs which cannot be done in isolation. He will have to necessarily interact with his immediate environment in others to achieve his aims and goals of self-satisfaction and self-actualization. The concept of the environment includes other men and works of nature, such as land, water and plant among others. This possibly explains why Aristotle argues that man is a political animal, which implies that a man will always interact with other men-man is a social being. The purpose of the interaction is to foster the life of happiness for him which is impossible if pursued nihilistically. For his goal of happiness to be achieved, without destroying the capacity of others' existence, rules and regulations (laws) are to be formulated and enforced to ensure that man's quest is done within the ambit of morality and legality. Thus, the emergence of those saddled with the responsibility of maintaining social order becomes an imperative. Here, we are confronted with the need for political leadership.

However, beyond getting some set of people to sit in the ivory tower of power, we must ensure that the mental dispositions of these personnel of government are well coordinated to enhance their favourable contribution to man's quest for happiness. This is because if these sets of people have dysfunctional behaviour or personality disorder, their policies and programmes will likely diminish man's capacity for self-actualization, self-fulfillment and self-satisfaction.

And there is no intellectual discipline within study of man that better captures this mental dimension of man's exercise of his rationality and humanity like psychology does. Therefore, the nexus between politics and psychology has gone beyond delineation.

In our quest for the well-being of the rural people, there is a need to consider the implication of government policies. This is because through inhumane policies, the government can frustrate the efforts of psychologists working to improve the well-being of the rural people. Therefore, this study re-interrogates the place of psychologists to ensure that the right people get into seats of power where decisions that will affect the general society, including the rural people, are made.

\section{Research Methods}

This research is carried out with the use of qualitative method with emphasis on the use of secondary data analyzed through textual and descriptive methods of analysis. The sources of the secondary data include books, journals, and articles among others. The discursive and dialogical method is the collecting and holding together in consistent form the multi-variety of opinions, perspectives and positions in which and through which being seeks to express and manifest its meaning in being [1]. It is observatory because it dwells on the observation of the political processes in Nigeria relying on empirical facts as recorded in the papers (academics and newspapers).

\section{Politics and Psychology: An Ideal Union}

It is important we state at this point that we deliberately avoided the use of the word, political science but chose to use politics because of the practical engagement we are driving at. The implication of this deliberate "avoid- 
ance" is to argue that the purpose of this paper is not just a mere intellectual interaction between political science (which is the study of politics) and psychology but rather a practical and field involvement of psychologists in political issues.

Even though the interaction can first begin as collaboration between the two titans (psychology and political science) within the field of social sciences, it must go beyond such to embrace a full blown recognition of the impact of psychology on the processes of politics within a country not as a mere academic discipline but as a necessity for man's quest for happiness to be achieved through the installation of the right kind of people for political leadership.

As noted by Abegunde, "there are two factors that influence the direction of development of a country. They are the character and nature of political leadership on the one hand and the system of governance in operation on the other" [2]. It is necessary to note that the political leadership determines the system of governance. So, if the character and nature of political leadership is faulty, then we can be rest assured that the system of governance would follow similar pattern.

\subsection{What Is Politics?}

Johnson holds that "politics concerns the formulation and execution of decisions binding upon the population of a community or society, and the relationship between those who make or implement such decisions and those who are affected by them" [3]. From the definition, politics focuses on the formulation and execution of decisions taken by some political leaders, whether in collaboration with the led through their representatives or by the political leaders without consulting the masses they represent, which will have either negative or positive effect on the general community of people. From this, it is obvious that some people formulate and execute policies which will affect some other people. Therefore, one could conclude that the effect of the policies on the people depends on the character and personality of those responsible for them.

For Kolawole, "politics is the nerve-centre of human peaceful and organized co-existence. It regulates other social systems so as to minimize and control conflict. Politics is part of all human beings" [4]. From this definition, politics is construed as central to organized human existence, regulating the behaviours of man and building a social system that will promote more of peace and less of conflict. In other words, with politics, conflict in human society should be minimal given the rules and regulations that prohibit inhumane, immoral and illegal behaviours among the citizens. We shall avoid the polemics between consensus view and conflict view of politics here. The point that is worth of note is that politics ought to make the lives of men better and not worse through the formulations and implementations of policies by political leaders for the benefit of the people they represent.

Faulks, Phillips and Thomson view politics as a response to certain inherent human problems and, in particular, the problems of order and distribution of resources [5]. Clearly discussed therefore, politics is expected to redress the problems of social disorder and ensure adequate distribution of collective resources of a country. But how best can we explain a situation where political leaders re-channel the resources to private purses.

It is at this point that abnormal behaviour becomes a subject of utmost importance under abnormal psychology, an authentic branch of psychology.

\subsection{What Is Psychology?}

Psychology, among several definitions, is often defined as the scientific study of the behaviours of organism (man and animal) and their mental process. Organismic behaviour is said to be hinged on both the environment and the organism's innate tendencies (natural predispositions) [6]. Psychology attempts at gaining an epistemic access into the mind of the human person leading to the possibility of understanding, explaining, predicting and correcting human behaviour. Given that the word "psyche" is translated to mean "mind", psychology is the study of the human mind.

The study of personality and its disorders has become central to the study of abnormal psychology [7]. A psychological disorder, or abnormal behavior, is a psychological dysfunction that is associated with distress or impairment in functioning and a response that is not typical or culturally expected. Abnormal behaviors are unexpected and often evaluated negatively because they differ from typical or usual behavior [8]. Abnormal psychology is the area of psychological investigation concerned with understanding the nature of individual pathologies of mind, mood, and behavior [9]. It is the study of mental and emotional disorders or maladaptive be- 
haviours, or of mental phenomena such as dreams, hypnosis, and altered states or levels of consciousness [10]. It is the branch of psychology that deals with modes of behavior, mental phenomena, etc., that deviate markedly from the standards believed to characterize a well-adjusted personality [11].

The Holy Bible reinforces the importance of the human mind, as it were psychology, in the book of Proverbs: "As he thinketh in his heart (mind), so he is" [12]. In other words, the personality and the behaviour of a man are determined by what goes on his mind.

We will like to cite Azenabor poignant submission on psychology and psychologists thus:

The psychologist aims at extending our knowledge of the human mind and behaviour and finding solutions to the problems of the individual as a person and that of the society at large through the study of human mind and behaviour. This study of behaviour refers to the mental process relating to ideas about human thought, development, attitudes, moods, intentions, volition, action, emotion, imagination, pleasure, dreams, ambitions and human needs. So psychology directs and enables us to understand our actions and attitudes [13].

From the above, the central importance of psychologists and their enterprise cannot be underestimated. The psychologists' aim at extending our knowledge of the human mind is not just for the purpose of theoretical discourse but to be able to ensure that we have a grasp of the causes and the effects of human behaviours on the society at large. It is not just problem discovery exercise but solution-oriented enterprise. All the inner experiences of man are discoverable by the psychologists with the use of some fundamental research tools and methods.

If psychology has such practical utility to humanity, we can convincingly and conveniently argue that it is a disservice to humanity for psychologists not to be proactive in issues of politics given that their enterprise deals with people (studies their social fitness) who wedge political power.

Laski holds that every government must submit itself to the judgment of those who feel the consequences of its acts [14]. The reason for such submission is the simple historical fact that unconditional power has always proved, at least ultimate, disastrous to those over whom it is exercise. If this statement is to be taken very serious, then those who exercise political power must be found to be fit for such expensive venture.

\section{Personality Disorder and the Imperativeness of Personality Test in Nigerian Politics}

It is a general observatory testimony that there are several human beings occupying positions of power in Nigerian politics that are not fit given the display of personality disorder.

Personality disorders are seen by professionals and researchers as an enduring pattern of inner experience and behavior that deviates markedly from the expectations of the culture of the individual who exhibits it [15]. Personality disorders are characterized by enduring, inflexible, and maladaptive patterns of relating to, perceiving, and thinking about the environment and oneself. They cause impairment in social and occupational functioning. Personality disorders may resemble personality characteristics that occur in people who are functioning adaptively. They may also resemble many different behaviours associated with anxiety disorders, psychoses, or mood disorders [16].

Nzongola-Ntalaja (1987) argues, many years ago, that it is the national ruling class itself that constitutes the principal obstacle to economic growth and development through the privatization of the state, depriving it of those essential means and capabilities with which to generate economic growth, improve the living conditions of the masses [17].

This observation is still very real in contemporary politics in Nigeria and in most African states.

The former EFCC (Economic and Financial Crime Commission) Chairperson (Mrs Farida Waziri) states her observation of Nigeria's political leaders thus:

The extent of aggrandizement and gluttonous accumulation of wealth that I have observed suggests to me that some people are mentally and psychologically unsuitable for public office. We have observed people amassing public wealth to a point suggesting madness or some form of obsessive compulsive psychiatric disorder [18].

The display of a high level of personality disorder in acquisition of private wealth out of the collective wealth of the nation beat the imagination of the anti-graft agency. The best description she could give of such height of quest for power and wealth was to put it within the framework of mental and compulsive psychiatric disorder.

In the field of psychology, to be specific, abnormal psychology, types of personality disorders are grouped 
under three clusters.

Cluster A: This is the realm of disorders that are odd or eccentric (weird)

Paranoid

Schizoid

Schizotypal

Cluster B: This is the realm of emotional and impulsive disorder

Antisocial

Borderline

Histrionic

Narcissistic

Cluster C: This is the realm of anxious and fearful disorders

Avoidant

Dependent

Obsessive compulsive

In all the clusters, Nigerian political leaders and governmental personnel display more of Cluster B. We may not need to highlight them one after the other, but we will like to examine some of these personality disorders as displayed by our leaders.

\subsection{Antisocial Personality Disorder}

This disorder is associated with crime, violence, and delinquency. The essential characteristics of this disorder include a history of continuous and chronic behaviour that violates the rights of others, begins before the age of 15, and continues into adult life [19]. More so, "it contains such repeated antisocial acts such as stealing, destroying property, and harassing others; repeated fights or assaults; failure to honour financial obligations; failure to plan ahead; ... and lack of remorse upon harming others" [19].

People suffering this personality have little or no regards for others and violate the rights of people around them. They are generally referred to as psychopaths or sociopath. They fail to conform to a given norm and will break all rules that lead to their arrest. They are used to lying, conning people and using aliases mostly for personal gain and pleasure. They never show remorse for their actions and never honor any emotional or financial obligations [20].

On January 1st 2012, the President of the nation hiked fuel price to above N100 not minding that the citizens would have exhausted their resources on the December festive period. He made life unbearable at the beginning of the year. A lot of people found it difficult to travel back to their stations having gone to their different states, towns and villages to celebrate the festive period (end of the year) with their family. We do not mean that the removal of the fuel subsidy is wrong but that it could have been done at a better time without necessarily inflicting financial and mental injuries on the people. This is just one out of many display of self-centered and emotional detachment from the followers demonstrated by people who are better described as rulers and not leaders.

The battle between the Presidency and the Governor of Rivers State is still an example of politics of disregard for the feelings of the people who bear the brunt of their disagreement. This is an example of personality disorder-antisocial personality disorder and narcissism.

\subsection{Borderline Personality Disorder}

Borderline individuals tend to have intense and unstable interpersonal relationships. A person may be valued as a wonderful friend one day and suddenly cut off the next day. Often there is a manipulative quality to these relationships [21].

This disorder has several features but above all else, the people suffering from this are extremely manipulative and have little or no empathy. They have a knack of pulling people towards them, then neglecting them and again bring the same person close to them. One is confused about their real nature as they keep changing their personality like one changes clothes [20].

Manipulation and deception are constant words in our political lexicon in Nigeria. One of the questions that are recurrent in politics is what are the political ideologies of our political parties? We, in the field of Political Science, have been able to X-ray the ideological bent of our political parties, but the political leaders have not been able to identify consistently what they stand for. What we experience is this consistent cross-carpeting 
(deflecting) from one political parties to another not on the basis of ideological antagonism but that of the quest for realizing personal ambition.

Borderline individuals also show disturbance in their concepts of identity: uncertainties about self-image, gender identity, values, loyalties, and goals [20]. Adolf Hitler is said to have suffered from this personality disorder.

\subsection{Histrionic Personality Disorder}

According to Sarason \& Sarason, "for people with histrionic personality disorder, getting the attention of others is a high priority.... It is manifested in cases of exaggerated expressions of emotion, stormy interpersonal relationships, a self-centered attitude, and manipulativeness" [22].

Patients with this condition are hungry for attention, over emotional and over dramatic. They draw people towards them by their flirtatious or seductive nature. But they, themselves, are emotionally shallow. They are easily bored and live in their own romantic, sweet world. They become extremely uncomfortable when the center of attention shifts from them. These patients show extreme self-dramatization and can easily influence any person with their exaggerated emotional expressions [20]. It is very rare to hear of a politician in Nigeria who refuses to vie for another tenure when his/her tenure in office ends. Our politicians always want to be at the center of socio-political attention given the economic benefits attached. The Obasanjo's third term agenda is a testimony. It is a general culture embraced by our politicians but it is a proof of personality disorder.

We can count on our finger tips many Governors who are now Senators. As soon as they exhausted their two term tenures, their personality disorder led them to seek another place of prominence in public glare.

\subsection{Narcissistic Personality Disorder}

The word narcissims comes from the Greek myth about a young man, Narcissus, who fell in love with his reflection in a pond. Because he could never grasp the image, which he thought was a water nymph, he sorrowed and ultimately died [23].

In this disorder, patients are craving for admiration, self-importance and show lack of empathy. They cannot stand criticism or losing to someone. These people often exaggerate their talents, achievements and feel superior to others. They feel they are special, and can only be understood by people who are equally talented or unique. They will take advantage of any person or situation till they get what they want. They feel others are envious of them and will themselves show signs of heightened envy. Haughty behavior sprinkled with arrogant attitudes can be a sign of narcissistic personality [20].

People with a narcissistic personality disorder are often preoccupied with fantasies of unlimited success and brilliance, power, beauty, and ideal love relationships. They may think of their problems as unique and feel that only other equally special people are able to understand them [23].

The patient displays excessive self-admiration and self-centeredness. We are witnesses to how our politics is built on the quest for self-actualization of the leaders' aspirations. Politics is played at the expense of the wellbeing of the citizens. The assassination of opponents is one of the issues we are still confronted with till today. The Dele Giwa untimely death, Bola Ige, Funsho Williams, Kayode Daramola, Kudirat Abiola, M.K.O, and the assassination of some unsung journalists and activists are all testimonies of personality disorders in our politics.

It is at this point we could conclude that most of our politicians in Nigeria are suffering from megalomania-which is an excessive enjoyment in having power over others.

\section{Histo-Empirical Realities of Personality Disorders in Political Leadership in Nigeria}

From the First Republic to the present Fourth Republic, personality disorders have been so displayed in our political life in Nigeria. From the few personality disorders outlined above, the absence of human feelings (inability to empathize with the masses), obsessive compulsion towards power and wealth acquisition exercised by our leaders further confirm that there is a need for personality test for those who intend to mount the throne of leadership in Nigeria.

The editorial of the Daily Times Newspaper of January 16th, 1966 poignantly captures the nature of both the civilian and the military rule thus: 
With the transfer of authority of the Federal Government to the Armed Forces, we reached a turning point in our national life. The old order has changed, yielding place to a new one... For a long time, instead of settling down to minister to people's needs, the politicians were busy performing series of seven day wonders as if the act of government was some circus show... still we groped along as citizens watched politicians scorn the base by which they did ascend... [24].

The people were manipulated and deceived with good promises that were never intended to be fulfilled. As soon as they get into power, the people become mere appendixes to our political processes — only needed for awhile and discarded after use. They centralize both political power and the collective resources of the nation. From the quote above, there is an obvious display of antisocial personality disorder and narcissistic behaviour.

Dash, reflecting on the Third Republic, holds that over \$16 billion in oil revenues were lost between 1979 and 1983 during the reign of President Shehu Shagari. According to him, it became quite common, for federal buildings to mysteriously go up in flames, most especially just before the onset of ordered audits of government accounts, making it impossible to discover written evidence of embezzlement and fraud [25].

In the same vein, in the military regime that followed the second Republic, leaders who were convicted of corruption found themselves back to public life with their seized properties released to them. The 1994 Okigbo Panel Report on the Reorganisation and Reform of the Central Bank of Nigeria indicted former Military President, General Ibrahim Badamosi Babangida, former Head of State, late General Sani Abacha, and former Governor of the Central Bank of Nigeria, the late Alhaji Abdulkadir Ahmed, for mismanaging about \$12.4 billion oil windfall between 1988 and 1994. A summary of the panel's report submitted to the Federal Government revealed that General Ibrahim Babangida's regime conspired with top officials of the Central Bank of Nigeria to squander the entire fortune on unproductive or dubious projects [26].

In order to forestall the continual perpetration of corrupt practices in our politics, Obasanjo inaugurated ICPC on 29th September 2000 and the EFCC in 2003. These anti-graft agencies have been able to expose some cases of corruption even though corruption has multiplied in the country. The former focuses on corruption in the public sector, especially cases of bribery, gratification, graft, and abuse or misuse of office (The Corrupt practices and other Related Offences Act, 2000) while the latter investigates people in all sectors who appear to be living above their means (EFCC_Economic and Financial Crime Commission).

From Adekeye's submission, political parties could be said to be the domain of this displayed of personality disorders in Nigeria. According to him, "a survey on the level of corruption in Nigeria carried out in 2003 by the Institute of Development Research of the Ahmadu Bello University, Zaria ranked political parties in the country third in the list of thirty most corrupt public institutions in Nigeria" [27].

If multi-national corporations would conduct personality test to be able ascertain who to recruit and where they should be placed, it is an imperative that in the management of public resources and governance, those aspiring to be involved need to go through this personality test too given the enormous task of managing both natural and human resources.

\section{Selected Cases of Indicted Public Office Holders}

Dada (2013) compiled cases of Public Office holders' indictments and we found these very germane in establishing the nature of personality disorders in Nigeria's politics. What follows from here are details as provided by Dada in his write-up, "how they looted Nigerian dry and a litany of abandoned EFCC corruption cases" [28].

1) Chief Bode George was arraigned by the Economic and Financial Crimes Commission (EFCC) alongside five other suspects (Aminu Dabo, Olusegun Abidoye, Adullahi Tafida, Zanna Maidaribe, and Sule Aliyu) on a 163-count charge (truncated to 68-count charge) that bordered on an alleged misappropriation of Nigeria Ports Authority (NPA) funds to the tune of N85 billion, and inflation of contract costs contrary to Section 22(3) of the Corrupt Practices and Other Related Offences Act, 2000.

2) Chimaroke Nnamani

The Economic and Financial Crimes Commission (EFCC), on August 10th, 2009, sealed off the premises of Cosmo FM Radio Station, Rainbownet Nigeria Limited and other companies believed to be owned by the exgovernor of Enugu State, who later became a Senator of the Federal Republic. The properties were seized by the EFCC through a Lagos Federal High Court order in May 2007 following the indictment of Nnamani over al- 
leged corruption and embezzlement of state funds to the tune of N5.3 billion.

After arraigning the ex-governor in court for prosecution, it appears the case had been stepped down because on September 25th, 2010 there was neither conviction nor an acquittal. Rather, the case is suffering prolonged adjournments and is still pending. He was a member of the Senate between 2007 and 2011.

3) Alao Akala

EFCC had arraigned Alao-Akala, a former Commissioner for Local Government and Chieftaincy Matters and incumbent senator, Hosea Agboola; and a businessman, Femi Babalola, over alleged misappropriation of N11.5 billion. The EFCC had accused the trio of conspiracy, illegal award of contracts, obtaining money by false pretence and acquiring property with money derived from illegal act as well as concealing the ownership of such property. One of Alao Akala's co-conspirators is a serving senator of the Federal Republic of Nigeria.

4) Orji Uzor Kalu

Former Abia State Governor Orji Uzor Kalu was arraigned on July 27th, 2007 before an Abuja High Court on a 107 count charge of money laundering, official corruption and criminal diversion of public funds in excess of N5 billion. He approached the Court of Appeal to set aside the ruling of the Federal High Court that he had a case to answer. The appellate court dismissed the appeal for lack of merit and gave the anti-graft agency the nod to prosecute him. With the charges still hanging on his neck, the former governor is touting himself as a possible presidential candidate in 2015. He still strolls around till date not only as a free man, but as a self-acclaimed spokesperson for the Igbo people.

5) James Ibori

On December 12th, 2007, Ibori was arrested by the Economic and Financial Crimes Commission (EFCC) at the Kwara State Lodge in Asokoro, Abuja. The charges he faced included theft of public funds, abuse of office, and money laundering. These corruption charges brought against Ibori by the government of former President Obasanjo are among many begun by anticorruption czar Nuhu Ribadu against former officials of the ruling People's Democratic Party PDP.

Ribadu additionally alleged that Ibori attempted to bribe him to drop the charges with a cash gift of $\$ 15$ million, which Ribadu immediately lodged in the Central Bank of Nigeria CBN. The cash remains in the CBN as an exhibit.

On December 17th, 2009, A Federal High Court sitting in Asaba, Delta State, discharged and acquitted Ibori of all 170 charges of corruption brought against him by EFCC. The EFCC filed a notice of appeal against the December 17th, 2009 judgment, and had begun a new round of investigations on the former governor following a petition by members of the Delta State Elders, Leaders and Stakeholders Forum, which was made available to the public in March 2010.

In April 2010, about three months after the takeover of government by Goodluck Jonathan, Ibori's case file was reopened. A new allegation that he embezzled N40 billion ( $\$ 266$ million) was pressed against him. Attempts to arrest him were unsuccessful. It was reported that he fled from Abuja to Lagos and then to the creeks of Oghara, his homeland in the Niger Delta. It was reported that he has been guarded by armed militias and they once had a shootout with government security forces. He claimed that the charges were frivolous and that he was a victim of political persecution.

In April 2010, Ibori fled Nigeria, prompting the EFCC to request the assistance of Interpol [15] [16]. On July 12th, 2010 the Governor of the CBN, Malam Sanusi Lamido revealed that Ibori had used Delta State as collateral for N40 billion loan when he was governor. He was later arrested in Dubai and extradited to the UK where he is currently serving jail terms for money laundering.

6) Lucky Igbinedion

In January 2008, Lucky Igbinedion, a former Governor of Edo State, was declared wanted by the Economic and Financial Crimes Commission on 142 counts of financial fraud. This concerns allegations that he embezzled $\$ 24$ million (£12 m) using front companies.

The former governor's overseas properties are valued conservatively at about N6 billion. Some of the identified overseas properties include: Mansion in Cape Town, South Africa, numerous houses in Johannesburg, South Africa. The famous Kenwood mansion in United Kingdom (UK), valued at $£ 3.3 \mathrm{~m}$ and paid for in one day. Igbinedion did not only embark on a shopping spree, he also set up a vast business empire. His younger brother, Bright, is allegedly the overseer of his estimated N7 billion business in South Africa. It includes the five-star Hotel Constantia along Airport Road in Benin-City, managed by his wife, Eki Igbinedion. The hotel is valued at about $\mathrm{N} 4$ billion. 
Chief Lucky Nosakhare Igbinedion was arraigned by the Economic and Financial Crimes Commission (EFCC) before the Federal High Court, Enugu in charge No. FHC/EN/6C/2008 on a 191-count charge of corruption, money laundering and embezzlement of N2.9b. In a plea bargain arrangement, the EFCC through its counsel Mr. Rotimi Jacob reduced the 191-count charge to one - count charge. The single charge read:

That you, Lucky Igbinedion (former Governor of Edo State) on or about January 21th, 2008 within the Jurisdiction of this honourable court neglected to make a declaration of your interest in account No.

41240113983110 with GTB in the declaration of assets form of the EFCC and you thereby committed an offence punishable under section 27(3) of the EFCC Act 2004.

The terms of the plea bargain were that the prosecutor would reduce the 191—count charge to one-count charge and in return, Lucky Igbinedion will refund N500m, 3 properties and plead guilty to the one-count charge.

Also, the former Bayelsa State Governor, Diepreye Alamieyeseigha, disguised as a woman and jumped bail in the UK. Today, he represents President Goodluck Jonathan in functions and takes the front seat at party functions.

\section{Conclusions from the Statistics}

It is obvious that our leaders need quick psychiatric intervention given their obsessive pursuit of wealth at the expense of the well-being of the citizens. They could be said to be suffering from hypertensive materialismunquenchable thirsty for material wealth [29]. They have suddenly lost their moral sense and pursue the path of plundering the treasury of the nation.

As seen above, the judiciary has not proven to be exempted from these personality disorders that have bedeviled our politics in Nigeria. This arm of government has added more salt to our injury by aiding these political leaders, perverting justice and letting them go off the hook of the law.

As it is well known that the environment could contribute to personality disorders, the social-political terrain in Nigeria has convinced aspiring leaders that mismanagement of public funds is a norm as against transparency and accountability. Therefore, there is a perennial recruitment of government personnel, whether political leaders through elections or institutional leaders through appointment, who are already disoriented on the true nature of political power and hence are willing to demonstrate, overtly or covertly, personality disorder (abnormal behaviour)

If we do not rise up to remedy this problem, things may likely be going worse in this country.

\section{Recommendations}

In order to change the face of things in Nigerian politics, the intellectual discipline that has the capacity to understand, explain, predict and correct human behaviours should take a lead while working with other disciplines. First, the Nigerian Psychological Association should create fora where issues of leadership are held to high premium. In other words, this noble association should come to term with the fact that it has an important role to play if these personality disorders displayed in corrupt practices have to stop in this country. Of course, there are several branches of the discipline, but the need on ground in our country centers on right leadership. If this is going to be achieved, we cannot hide under the umbrella of being specialists outside scope of our need. Thus, abnormal psychology becomes one of the important branches that must be "marketed" to the nation.

The association, among other things, should champion the need for personality test for those vying for public offices. It may take some time before this idea is bought but the consistency can create awareness in the minds of the citizens of the correlation between psychological/mental illness and bad governance, psychological/mental wellness and good governance.

Second, the curriculum of our universities should be redressed so as to give room for psychology to be taken as a compulsory NUC course just as philosophy was adopted. This will enlighten the populace about the central place of this discipline in any human society.

Third, on the level of individual, psychologists should make the discipline attractive to the larger society by getting involved in national issues, especially on leadership and good governance, as professionals and not mere citizens.

Fourth, we should transcend the stage of mere debate on the validity, reliability, quantification and measure- 
ment of personality test to a stage of using what we have to achieve our purpose. In other words, let us slow down on the debate of how potent the test will be or not be, and begin the test now. We should outgrow our theoretical polemics and move to the stage of practical engagement with socio-political realities in our country.

Finally, let us start now! Let us save our country from being ruled by men and women who are best described, in the word of Waziri Farida, as psychiatric patients.

\section{References}

[1] Odimegwu, I. (2008) Integrative Personhood: A Communalist Metaphysical Anthropology. Lit Verlag, Berlin, 82.

[2] Abegunde, O. (2010) Politics and Governance in Nigeria. In: Omotoso, F., et al., Eds., Governance, Politics and Policies in Nigeria: An Essay in Honour of Prof. Dipo Kolawole, Editions SONOU d'Afrique (ESAF), Porto Novo, 104115.

[3] Johnson, L. (2001) Politics: An Introduction to the Modern Democratic State. Broadview Press Ltd., Peterborough, 18.

[4] Kolawole, D. (2005) Concepts of Politics. In: Kolawole, D., Ed., Readings in Political Science, Dakaal Publishers, Ibadan, 1-14.

[5] Faulks, K., Phillips, K. and Thomson, A. (2003) Get Set For Politics. Edinburgh University Press Ltd., Edinburgh.

[6] Ogunleye, A.J. and Abe, G.O. (2004) Psychology and the Environment: A Psycho-Political Analysis. In: Ogunleye, A.J., Ed., Contemporary Politico-Psychological Issues, Olugbenga Press \& Publishers, Ado-Ekiti, 57-73.

[7] Millon, T., Grossman, S., Millon, M. and Ramnath, R. (2004) Personality Disorders in Modern Life. 2nd Edition, John Wiley \& Sons Inc., Hoboken.

[8] Durand, V.M. and Barlow, D.H. (2003) Essentials of Abnormal Psychology. 6th Edition, Cengage Learning, Wadsworth.

[9] Gerrig, R.J. and Philip, G.Z. (2002) Psychology and Life. 16th Edition, Allyn and Bacon, Boston.

[10] The American Heritage (2009) Dictionary of the English Language. 4th Edition, Houghton Mifflin Company, Boston.

[11] Random House (2010) Webster's College Dictionary. Random House Inc., New York.

[12] The Holy Bible (1997) Proverbs. Tyndale House Publishers, Inc., Wheaton.

[13] Azenabor, G. (2001) The Nature and Scope of Philosophical Psychology. In: Azenabor, G., Ed., Philosophical Psychology: Selected Readings, Malthouse Press Ltd., Lagos, 1-120.

[14] Laski, H.J. (1967) A Grammar of Politics. 5th Edition, George Allen and Unwin Ltd., London.

[15] Grohol, J.M. (2013) Personality Disorders. http://psychcentral.com/personality/on27-10-2014by1.00a.m

[16] Sarason, I.G. and Sarason, B.R. (1987) Abnormal Psychology: The Problem of Maladaptive Behavior. 5th Edition, Prentice-Hall, Inc., Englewood Cliffs.

[17] Nzongola-Ntalaja, G. (1987) The Crisis in Zaire. In: Africa' Crisis, Institute for African Alternative, London, 7-26.

[18] Waziri, F. (2009) The Punch Newspaper. Wednesday, 30th September, 2009.

[19] Sarason, I.G. and Sarason, B.R. (1987) Abnormal Psychology: The Problem of Maladaptive Behaviour. 5th Edition, Prentice-Hall, Inc., Englewood Cliffs, 249.

[20] Baxamusa, B.N. (2012) Personality Disorder. http://www.buzzle.com/articles/abnormal-psychology-personality-disorders.html

[21] Sarason, I.G. and Sarason, B.R. (1987) Abnormal Psychology: The Problem of Maladaptive Behavior. 5th Edition, Prentice-Hall, Inc., Englewood Cliffs, 247.

[22] Sarason, I.G. and Sarason, B.R. (1987) Abnormal Psychology: The Problem of Maladaptive Behaviour. 5th Edition, Prentice-Hall, Inc., Englewood Cliffs, 248.

[23] Sarason, I.G. and Sarason B.R. (1987) Abnormal Psychology: The Problem of Maladaptive Behaviour. 5th Edition, Prentice-Hall, Inc., Englewood Cliffs, 245.

[24] Daily Times (1966) The Editorial Column.

[25] Dash, L. (1983) Mysterious Fires Plague Nigerian Investigations. The Washington Post.

[26] Ogbeidi, M.M. (2012) Political Leadership and Corruption in Nigeria since 1960: A Socio-Economic Analysis. Journal of Nigeria Studies, 1, 1-25.

[27] Adekeye, F. (2003) 30 Most Corrupt Public Institutions in Nigeria. Newswatch, December 22.

[28] Dada, S. (2013) How They Looted Nigerian Dry and a Litany of Abandoned EFCC Corruption Cases. The Neighbourhood. 
http://www.theneighbourhood.com.ng/for-the-record/1491-how-they-looted-nigeria-dry-and-a-litany-of-abandoned-efc c-corruption-cases.html

[29] Agbude, G.A., Adoba, I.O. and Etete, P.I. (2013) Ethics of Development: Kant and Cabral's Pragmatic Contributions. Journal of Research on Humanities and Social Sciences, 3, 1-9. 
Scientific Research Publishing (SCIRP) is one of the largest Open Access journal publishers. It is currently publishing more than 200 open access, online, peer-reviewed journals covering a wide range of academic disciplines. SCIRP serves the worldwide academic communities and contributes to the progress and application of science with its publication.

Other selected journals from SCIRP are listed as below. Submit your manuscript to us via either submit@scirp.org or Online Submission Portal.
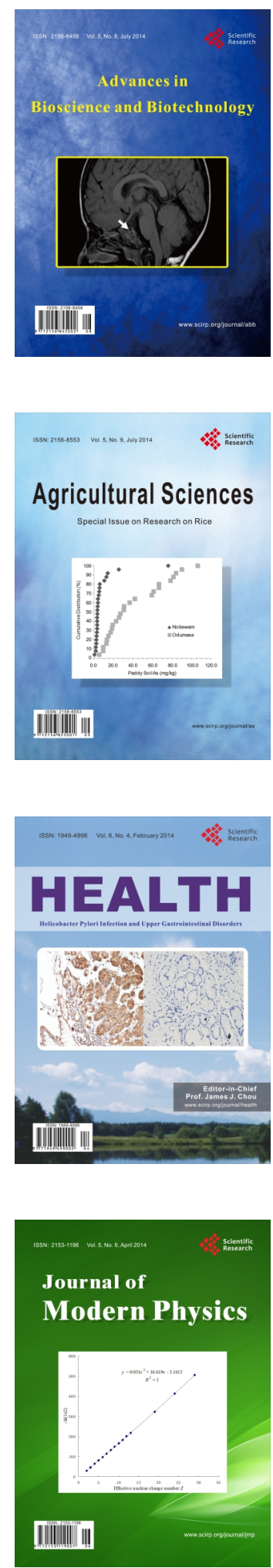
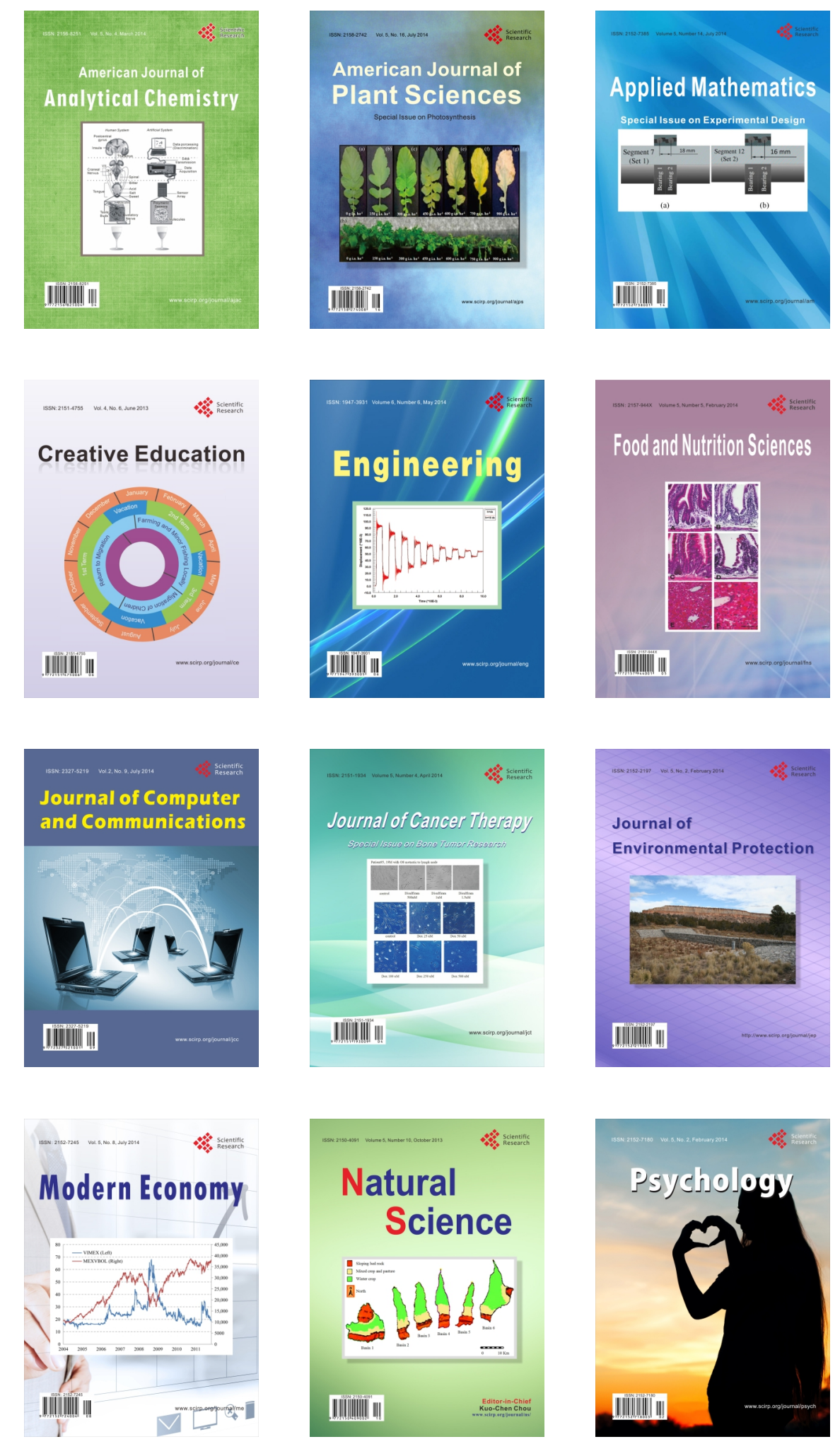